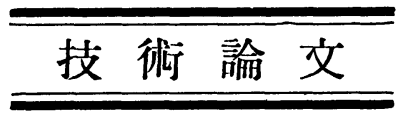

\title{
アルミニウム焼鈍板の再結晶聚合組織と異方性におよぼす 鋳塊予備加熱の影響についで
}

\begin{abstract}
網 谷 俊 男**
Toshio Amitani: On the Effect of Preheating Conditions' on the Recrystallization Texture and Anisotropic Properties of Annealed Aluminium Sheets.

The problem of the anisotropic properties of aluminium sheets is regarded as of great importance to makers because of the "earing" phenomena which occur during deep drawing. Experiments were carried out to study the effect of preheating ingots on the anisotropy and recrystallization texture of the annealed aluminium sheets. By the present investigation the following results were obtained: (1) In the aluminium sheet which was hot-and cold-rolled from the ingot without any intermediate annealing treatment, the recrystallization texture and the anisotropy of the annealed sheet depend on the preheating temperature and time before rolling. (2) The above effect of preheating was not observed in high purity aluminium, but in commercial aluminium. This implies that the effects are concerned with the impurity elements in the aluminium ingots. (3) When a commercial purity aluminium ingot was preheated and rolled the recrystallization texture of the annealed sheet retained most of the main component of the rolling texture (123) [121] , and this results in a $45^{\circ}$ earing by deep drawing. When the ingot was not preheated, the second orientation (100) [001] appeared and a $90^{\circ}$ earing was observed. (4) It was revealed by microscopic observation and electric resistance measurement that the precipitation of impurities is introduced by the preheating treatment of the ingot. It may be possible to conclude that the changes in the anisotropy and the recrystallizating texture are induced by the precipitation of the impurities when the ingot is preheated.
\end{abstract}

(Received June 30, 1960)

\section{I. 緒}

フルミニウムは压延されると(110)[112] むたは (123) [12̄1]の压延聚合組織 (rolling texture)を発生し,これに よつて諸性質に異方性が現われることはかなり以前から知 られていた(1)・(3).最近になつてこれらの压聚合組織を 有する圧延板を垷鈍して再結晶聚合組織 (recrystallization texture) にした場合の詳細な研究が行われるように なつた．この再結晶聚合組織とその焼鈍以前の压延聚合組 織との関係については Beck, Hu(4) の研究があり, (123) [12 1$]$ の方位を有する結晶が [111]軸である角度回転して (100) [001] の再結晶聚合組織となることを極点図 (pole figure) で示している. 压延聚合組織によつてアルミニウ 厶板の諸性質の異方性が現われると同様に, 再結晶聚合組 織に上つても異方性が現われるが, 就中深絞加工の時に現

** 住友軽金属工業株式会社研究部

* 1959 年 11 月本会大阪大会に発表

(1) E.A.Owen and G.D.Preston: Proc.Phys. Soc., $38(1925), 132$.

(2) G.Wasserman: Texture Metallisher Werkstaffe, (1939) .

(3) H.Hu,P.R.Sperrey and P.A.Beck: J.Metals, $4(1952), 76$.

(4) P.A.Beck and H.Hu : Trans. AIME, 188 (1950), 1215 .
われる“耳” (earing)の発生に関して最も敏感である. 聚 合組織と耳の発生条件との相関性については麻田(5), 山口 (6), 前田(7), 烟(8)の研究があり, また Aust, Morrel(9) は Hill の塑性変形の理論から論じている.これらによれば,

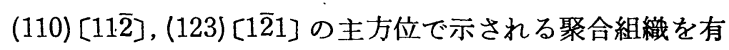
するものは，任延方向に対して $45^{\circ}, 135^{\circ}, 225^{\circ}, 315^{\circ}$ の 4 ケ の耳を発生し，また(100)[001]で示される聚合組織を有す るものは压延方向に対して $0^{\circ}, 90^{\circ}, 180^{\circ}, 270^{\circ}$ の 4 ケの耳 を発生する事が判つた．この結果再結晶聚合組織の中でる 圧延聚合組織に発生した (110) [11 $2 \overline{2}],(123)[1 \overline{2} 1]$ を比較的 多量に残留し，再結晶の際発生する(100)[001]を比較的少 なく有するようなものは深校加工で $45^{\circ}$ の耳を発生する. これと反対に大部分 (100)，[001] の優越方位を有する焼鈍 板は $90^{\circ}$ の耳が発生することが示されている．烟(8)によれ ば異方性の殆んぞないもの，すなわち耳.発生しないアル ミニウム焼鈍板はその再結晶聚合組織が(110), [11 2 ],$(123)$,

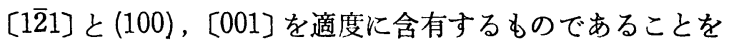
示した。これらの再結晶聚合組織の違いがアルミニウム焼

（5）麻田，小池：軽金属, No.5(1952)，35.

（6）山口，中村, 堀山：軽金属, No.2 (1952), 56 .

（7）前田, 渡辺: 日本金属学会秋期大会講演概要, (1951) .

(8) 烟, 竹内: 本誌, $18(1954), 371$. 
鈍板の異方性の違いとなつて現われるのであるが，この再 結晶聚合組織の違いは何が原因となつて現われるのであろ ろか.この点についての研究は比較的少なく詳細を知るに 充分ではない，原因がアルミニウム焼鈍板を製造する際の 製造因子に関するものとしての研究は，Spillet(10)，Hug (11), Sieble(12), Thorley(13), 烟(8) らの研究があり,また原 因がアルミニウム焼鈍板に含有する不純物に関するものと しての研究は最近Bunk(14) のものがある.

これらの研究の中でもアルミニウム鋳塊の圧延前の予備 加熱の影響について一応調査は行われているものもある が，詳細を知るには不充分と思われる点が多いので，この 点についての研究を行つた。

\section{II. 実 験 方 法}

試料は $99.5 \%$ 程度の純度を有するアルミニウムの 連 続 鋳造法によつて作つた約 $200 \mathrm{~kg}(750 \times 250 \times 396 \mathrm{~mm})$ 鋳 塊, 执よび $99.0 \%, 99.9 \%$ 程度の純度を有するアルミニウ ムの傾注法によつて作つた約 $2 \mathrm{~kg}(150 \times 170 \times 27 \mathrm{~mm})$ 鋳 塊を使用した. Table 1 に試料の分析値を示す. $200 \mathrm{~kg}$

Table 1 Chemical composition of specimens.

\begin{tabular}{l|l|l|l|l|l|l|l|l|l}
\hline & No. & $\mathrm{Cu}$ & $\mathrm{Si}$ & $\mathrm{Fe}$ & $\mathrm{Zn}$ & $\mathrm{Mg}$ & $\mathrm{Mn}$ & $\mathrm{Ti}$ & $\mathrm{Al}$ \\
\hline C.C.P. & 1 & 0.018 & 0.16 & 0.37 & 0.014 & 0.001 & 0.01 & 0.01 & 99.4 \\
\hline P.M. & 2 & 0.027 & 0.17 & 0.59 & 0.014 & 0.004 & 0.01 & tr. & 99.1 \\
& 3 & 0.002 & 0.06 & 0.004 & 0.009 & 0.006 & tr. & tr. & 99.97 \\
\hline
\end{tabular}

の連続鋳造法によつて作つた鋳塊からはFig.1に示すよ ろな要領で試料を切出し $100 \times 200 \times 25 \mathrm{~mm}$ の寸法のもの を採取した.これらの表面を切削して約 $20 \mathrm{~mm}$ とし，

Table 2 で示す温度扣よび特間で予備加熱を行い，一旦常

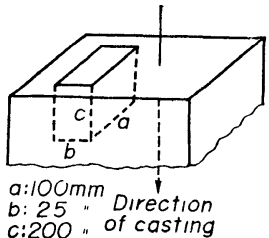

c:200 " of casting

Fig. 1 Extraction method of specimen. 温に空冷し再び 全部 $400^{\circ}$ に加 熱しその温度で約 $10 \mathrm{~mm}$ まで 圧延加工した。途中で焼鈍する ことなく常温で圧延して $1 \mathrm{~mm}$ の板に仕上げた．完成したアル ミニウム圧延板を $350^{\circ}$ で 1 時 間烍鈍した後，X線によつて聚 合組織の検討を行い円錐型ダイ

Table 2 Preheating condition of aluminium ingots.

\begin{tabular}{c|ccccc}
\hline Temperature & $400^{\circ}$ & $450^{\circ}$ & $500^{\circ}$ & $550^{\circ}$ & $600^{\circ}$ \\
\hline Time & 0 & $8 \mathrm{hr}$ & $24 \mathrm{hr}$ & $96 \mathrm{hr}$
\end{tabular}

ス(Conical dies)による深絞試験を行つた. 圧延方向に対 して $45^{\circ}, 135^{\circ}, 225^{\circ}, 315^{\circ}$ の 4 ケの耳を発生したものを

(9) K.T.Aust and F.R.Morrel: J.Metal,3(1953), 431.

(10) E.E.Spillet: J.Meta1, $1(1943), 149$.

(11) H.Hug: Metall, 9(1955), 176.

(12) G.Sieble: Meta11, 6(1952),529.

(13) R.T.Thorley: J.I.M., 86(1957 58), 353.

(14) Walfgang Bunk: Z.Metalk.,50(1959), 218. $45^{\circ}$ 耳としまた $0^{\circ}, 90^{\circ}, 180^{\circ}, 270^{\circ}$ の 4 ケの 志を発生し たものを $90^{\circ}$ 耳とした. 異方性の強弱に閵しては Fig.2に

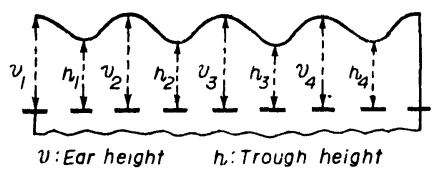

E.H. (mean ear heigist)

$$
=\frac{\left(v_{1}+v_{2}+v_{3}+v_{4}\right)-\left(h_{1}+h_{2}+h_{3}+h_{4}\right)}{4}
$$

Fig.2 Measurement of earing.

示すよ5な方法で高さを測定しこの平均值をもつて耳の高 さとし異方性の強弱とした。

\section{III. 実 験 結 果 と 考 察}

温度を $4.00 〜 550^{\circ}$ の各温度に保持し，洔間を $1 \mathrm{hr} \sim 96 \mathrm{hr}$ の間に変化して鋳塊を加熱して予備加熱条件の 異なる種 々の鋳塊を作つた. 予備加熱後空冷し再び $400^{\circ}$ に加熱し その温度で約 $10 \mathrm{~mm}$ まで压延し空冷後すぐ $1 \mathrm{~mm}$ まで常

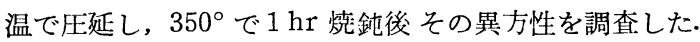

Fig.3に得られた結果を示す.

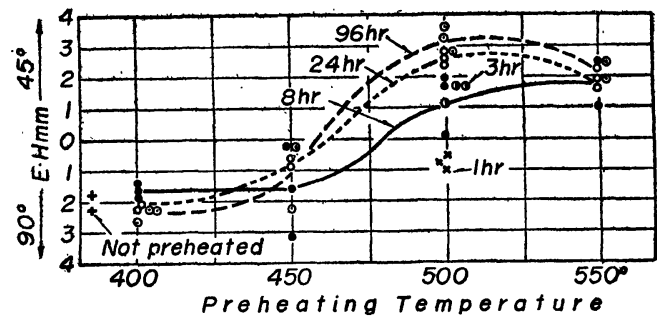

Fig.3 Earing of annealed commercial-purity aluminium sheet, showing effect of preheating temperature. Continuous casting ingot.

すなわら横軸に鋳塊予備加熱温度を示し，縦軸に異方性 を示して市る. 因から判るよ5に $500^{\circ}$ で $3 \mathrm{hr}$ 以上予備加 熱を行つたものから作つた焼鈍板は $45^{\circ}$ の耳.を発生するに も拘らずそれ以下の温度，例えば $450^{\circ}$ の場合は $96 \mathrm{hr}$ の鋳 塊予備加熱を行つても $90^{\circ}$ の耳を発生している，すなわち 鋳塊予備加熱は焼鈍㤆の異方性を支配する重要な因子であ ることが判つた。

次に高純度アルミニウム $(99.9 \%)$ 拈よび普通純度アルミ ニウム $(99.0 \%)$ の傾注法によつて作つた鋳塊に予備加熱を 行つて上記の影響について調査した結果をFig.4に示し た. 横軸に $500^{\circ}$ に打ける鋳塊の予備加熱特間を示し,縦軸 に異方性, 寸なわち深絞りの際発生する耳の発生方向が示 してある. 普通純度のアルミニウム鋳塊は連續鋳造法, 傾 注法によらず 500 で約 $2 \mathrm{hr}$ 以上の予備加熱を鋳地に加え ることによつてそれから作られた焼針板は $45^{\circ}$ の耳が発生 するように変化する。しかし高純度アルミニウムは鋳塊の 予備加熱に殆んど影響なく，その焼鈍板は $90^{\circ}$ の耳を発生 していることが判る.この事実は予備加熱は比較的不純物 を多く含有する普通純度アルミニウムの鋳塊に行うことに よつて始めてその焼鈍板の異方性に影響し，高純度アルミ 
ニウムのよ5に不純物含有量の少ない鋳塊は予備加熱によ つては影響されないことが判つた. Photo.1に鋳塊予備加

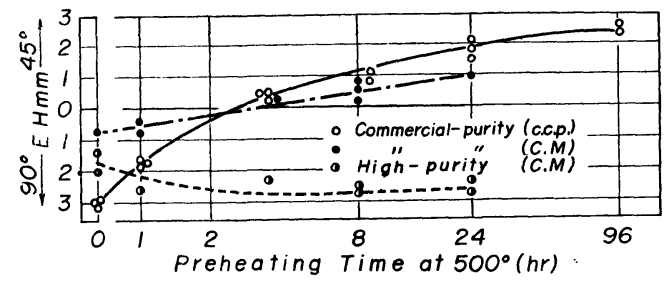

Fig.4 Earing of annealed high and commercia1purity aluminium sheets, showing effect of preheating time at $500^{\circ}$.

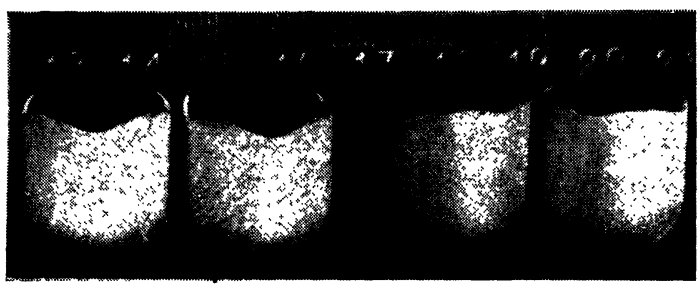

Photo. $17 \mathrm{~mm}$ dia cups drawn from $40 \mathrm{~mm}$ blanks, showing $45^{\circ}$-earing (left) and $90^{\circ}$-earing (right).

熱によつて最終焼鈍板の異方性が変化し，その結果異なつ た方向の耳を有する普通純度アルミニウム焼鈍板の深絞加 工後の状態を示した.

緒言に扣いて述べたように諸研究の結果によれば深絞試 験に扣ける耳の発生様式は試料の結晶学的聚合組織によつ て支配されるものと考えられるので，上記の鋳塊予備加熱 によつて異なつた方向に耳を発生した試料の極点図をX線 で決定した. 試料は両側より硝酸, 塩酸, 弗酸の混合液で 腐蝕し $0.5 \mathrm{~mm}$ とした. 生延方向执よびこれと直角方向を 軸としてX線を入射せしめ，入射方向に対して $15^{\circ}$ づつ傾

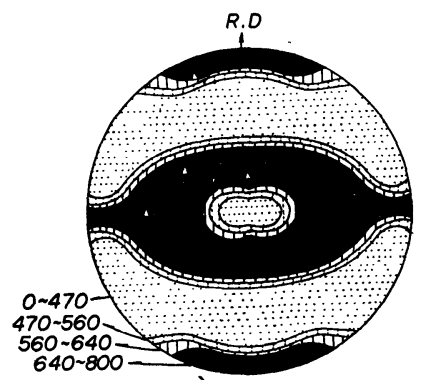

Fig.5 (111) pole figure of 90 percent rolled aluminium sheet made from the ingot preheated at $520^{\circ}$ in $8 \mathrm{hr}$. The positions of $(123),[1 \overline{2} 1]$ are indicated by $\triangle$.

のの方が圧延聚合組織で代表された (123)，[12 1$]$ 以外の第 二の新しい方位の強度が大である.この方位は (100),[001]

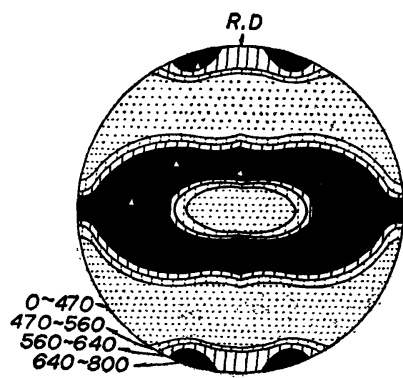

Fig.6 (111) pole figure of 90 per cent rolled aluminium sheet made from the ingot not preheated. The positions of (123), [12 1$]$ are indicated by $\triangle$.

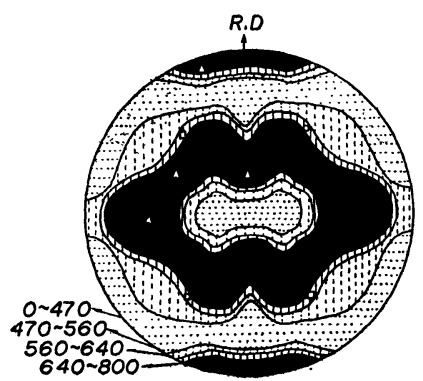

Fig .7 (111) pole figure of made annealed aluminium sheet made from the ingot preheated at $520^{\circ}$ in $8 \mathrm{hr}$. The positions of (123), [1 $\overline{2} 1]$ are indicated by $\Delta$ and $(100),[001]$ are indicated by $\square$.

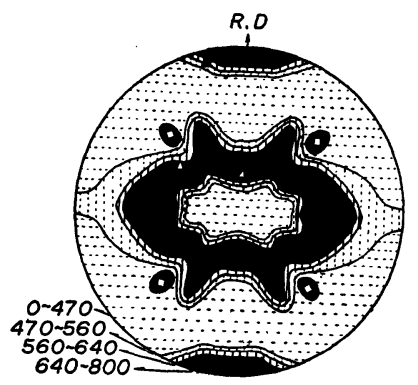

Fiig.8 (111) pole figure of annealed aluminium sheet made from the ingot not preheated. The positions of (123), [12 1$]$ are indicated by $\triangle$ and $(100),[001]$ are indicated by $\square$.
の方位として近似出 来るものと考えられ る. 鋳塊予備加熱は 最終焼鈍板の再結晶 聚合組織の優越方位 に圧延聚合組織の優 越方位を多く残留せ しめる効果があり， その結果 $45^{\circ}$ の耳を 発生するような異方 性をあたらしめるこ とが判つた。

次に鋳塊予備加熱 は鋳塊そのものに如 何なる変化を与える かについて検討を加 えた. Photo.2〜4 に高純度アルミニウ ム鋳塊および普通純 度アルミニウム鋳塊 を520に打いて予 備加熱した際の時間 的な組織变化を示し た. 普通度アルミニ ウムの組織は時間の 径過と共に粒内が粒 界から変化しで $8 \mathrm{hr}$ を径過すると粒内全 体に变化が拡がつて いることが観察出来 る、これに反し高純 度アルミニウムは全 く変化がないここれ は普通純度のアルミ ニウム焼鈍板の耳が その鋳塊予備加熱に よつて $90^{\circ}$ の方向か ら $45^{\circ}$ の方向に変る のに反し, 高純度ア ルミニウム焼鈍板に执いては耳の発生方向に変化がない事 実と対応するものと考えられるまむここ組織の変化は高 純度アルミニウム鋳渋に扎いて認められない点から, 含有 せられる不純物元素, 主に鉄, 硅素の挙動と思われる.こ れらの鉄, 硅素はアルミニウム鋳造の際の凝固期に扣いて アルミニウムと金属間化合物を作つて大部分第 2 相として

現われるが，鋳造の際の冷却速度が鋳塊が薄く速いのでな 熱を行つたものに比較してFig.8 の予備加熱を行わないる

は認められず，略:京一の極点図が得られ，Beck, Hu(4) の結果と一致している. この試料を $350^{\circ} て ゙ 1 \mathrm{hr}$ 焼鈍した もの, すなわち Fig.4 で示したように再結晶聚合組織の違 いから異方性が違つて $45^{\circ}$ まは $90^{\circ}$ の耳の発生したもの の極点㘠を Fig.7，8 に示した。 これによると雨試料の間 にはかなりの觅が現われている.すなわち Fig.7 の予備加 
お過飽和の状態にあると考兄られる(15)(16). 鋳䰠予備加熱 によつてこの渦飽和の状態に変化が生ずるものと推察され
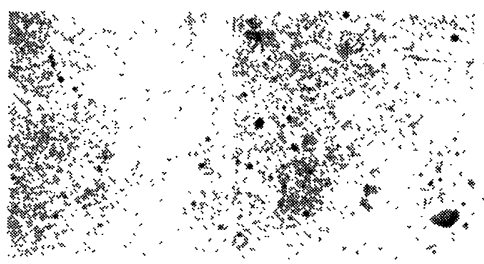

(a) not preheated

(b) $520^{\circ}, 1 \mathrm{hr}$

(c) $520^{\circ}, 8 \mathrm{hr}$

Photo.2 Microstructure of high-purity aluminium ingot (chill cast) preheated at $520^{\circ}$ in various time. $(\times 100 \times 2 / 3)$

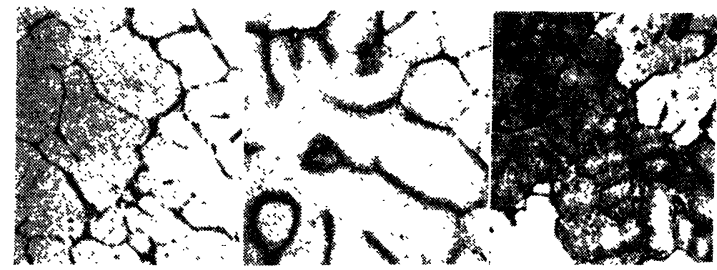

$\begin{array}{lll}\text { (a) not preheated (b) } 520^{\circ}, 1 \mathrm{hr} & \text { (c) } 520^{\circ}, 8 \mathrm{hr}\end{array}$

Photo.3 Microstructure of commercial-purity aluminium ingot (chill cast) preheated at $520^{\circ}$ in various time.

$(\times 100 \times 2 / 3)$

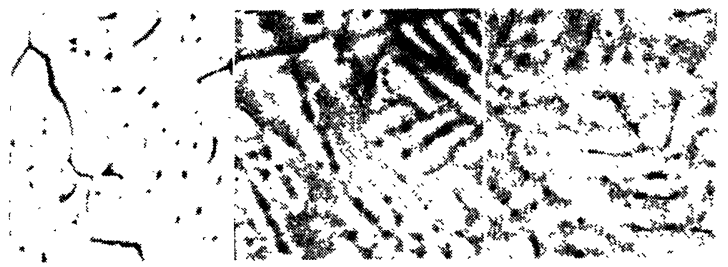

$\begin{array}{lll}\text { (a) not preheated } & \text { (b) } 520^{\circ}, 1 \mathrm{hr} & \text { (c) } 520^{\circ}, 8 \mathrm{hr}\end{array}$

Photo.4 Microstructure of commercial-purity aluminium ingot (contineous casting) preheated at $520^{\circ}$ in various time.

$(\times 100 \times 2 / 3)$
增大しているのは析出物が再溶解したためであろ5(Ed$\operatorname{ger}(17)$ にると平衡状熊で鉄のアルミニウム中への固溶度

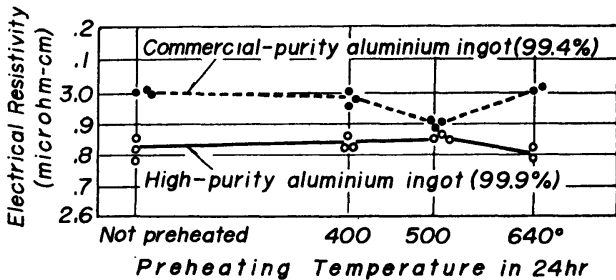

Fig.9 The effect of preheating on the electrical resistivity of aluminium ingot (chill cast). Specimens are quenched in water from each temperature and then measured.

は $655^{\circ}$ で $0.052 \%, 500^{\circ}$ で $0.006 \%$ である).この測定試料 の組織をPhoto.5に示した。この写真において $630^{\circ}, 400^{\circ}$ において加熱したものに 比較して $520^{\circ}$ において加熱した 試料の方が結晶粒内に析出物が多いように見受けられる.

以上の事実から予備加熱は鋳塊内に析出を与えるもので あることが判つた．もしこの析出物がアルミニウムの最終 焼鈍板の異方性に影響するものとすれば, $600^{\circ}$ 近傍におい て予備加熱したものはたとえ予備加熱を行つたといえ再固 溶化して析出物の量が减少しているので，予備加熱を行つ てないアルミニウム鋳塊から出発した焼鈍板の異方性に似 なければならない。これを確かめる月的で $600^{\circ} て ゙ ~ 96 \mathrm{hr}$ 予 備加熱を行つた鋳塊をその温度で $10 \mathrm{~mm}$ まで圧延し，以 下冷間王延して $1 \mathrm{~mm}$ とした焼鈍帊の異方性を調査した。 結果は予想した通り $520^{\circ}$ 予備加熱のものに比較して高温 で，予備加熱したにも拘らず高い $45^{\circ}$ の耳は発生せず，す なわち 0 ～ $2 \mathrm{~mm}$ 程度の高さを有する $0^{\circ}, 90^{\circ}$ の耳を発生す る焼鈍板であつた。

以上得られた実験結果に多少の推定を加えて要的すると Table 3に示すようになる。

るが，変化をさらに詳細に調査する目的で予 備加熱による鋳塊の電気抵抗の変化を調查し た. 予備加熱を適当に行つた鋳塊をその温度 から水中に焼入し $3 \times 3 \times 200 \mathrm{~mm}$ に切削して 測定した。得られた結果をFig.9に示す。図 が示すように高純度アルミニウム鋳塊の電気 抵抗には鋳塊予備加熱によつて変化がない が; これに比較して普通純度のアルミニウム 鋳䰠は $500^{\circ}$ 近傍の 加 熱で電気抵抗は減少し $640^{\circ}$ 近傍の加熱で再び増大している. $500^{\circ}$ 近

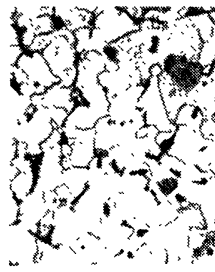

(a) $400^{\circ}, 2 \Delta \mathrm{hr}$
IV. 總括

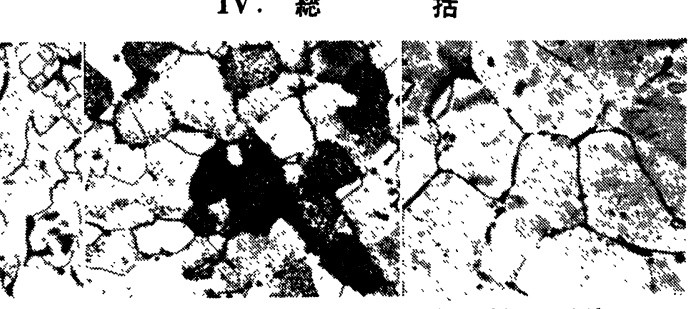

(c) $630^{\circ}, 24 \mathrm{hr}$
Photo.5 Microstructure of commercial-purity aluminium ingot, showing change by preheatig.

$(\times 100 \times 2 / 3)$

アルミニウム鋳塊に予備加熱を行つてその焼鈍板の再結 晶聚合組織と異方性におよぼす影響を調查し，次のような 結果を得た。

（1）中間焼鈍を行 こことなく鋳塊から熱閒および冷間圧 延されたアルミニウム板の焼鈍後の再結晶聚合組織, およ び異方性は生延前の鋳塊予備加熱温度および時間に支配さ れる。

(17) J.K.Edger: Trans. AIME, 180(1949), 225.

(15) G.Falkenhangen: Z.Metallk., 43 (1952), 69.

(16) A.Roth: Z.Metallk., 31 (1939), 299. 
（2）上記予備加熱つ影響は高純度了ルミニウムに打いて は認められず, 普通純度アルミニウムに拈いて認められる
つて $45^{\circ}$ の耳を発生する。 また予備加熱を行わない場合は 第二の方位 $(100)$, [001] が現われ $90^{\circ}$ の耳を発生する.

Table 3 Change of physical and anisotropic properties by preheating conditions.

\begin{tabular}{|c|c|c|c|c|c|c|}
\hline & $\begin{array}{l}\text { Preheating } \\
\text { temperature }\end{array}$ & $\begin{array}{l}\text { Microstructure } \\
\text { of ingot }\end{array}$ & $\begin{array}{l}\text { Electric } \\
\text { resistance } \\
\text { of ingot }\end{array}$ & Rolling texture & $\begin{array}{l}\text { Recrystalliza- } \\
\text { tion texture }\end{array}$ & $\begin{array}{c}\text { Anisotropy } \\
\text { (earing) }\end{array}$ \\
\hline $\begin{array}{l}\text { High-purity alumj- } \\
\text { nium }(99.9 \% \text { up) }\end{array}$ & $\sim 650^{\circ}$ & not changed & not changed & $(123)[1 \overline{2} 1]$ & $(100)[001]$ & $90^{\circ}$ \\
\hline \multirow{3}{*}{$\begin{array}{l}\text { Commercial-purity } \\
\text { aluminium } \\
(99.0 \% \text { up })\end{array}$} & $\sim 400^{\circ}$ & not changed & not changed & $(123)[1 \overline{2} 1]$ & $(100)[001]$ & $90^{\circ}$ \\
\hline & $450 \sim 550^{\circ}$ & precipitate & decrease & $(123)[1 \overline{2} 1]$ & $(123)[1 \overline{2} 1]$ & $45^{\circ}$ \\
\hline & $550 \sim 650^{\circ}$ & resolute & increase & $(123)[1 \overline{2} 1]$ & $\begin{array}{l}(100)[001] \\
(123)[1 \overline{2} 1]\end{array}$ & $90^{\circ}+45^{\circ}$ \\
\hline
\end{tabular}

ことから，アルミニウム鋳塊に含まれる不純物元素と関係 があることを意味する.

（3）普通純度アルミニウム鋳塊に予備加熱を加えるとそ の焼鈍板の聚合組織は圧正聚合組織による主方位 (123), [12 1$]$ が多く残留するようになり, その結果深絞加工によ
（4）顕微鏡組織の観察，および電気抵抗の測定結果鋳塊 予備加熱を行 らと不純物の析出が進行することが判つた. 異方性扣よび再結晶聚合組織に变化を与える大さな要因の 一つとして鋳塊予備加熱による不純物の析出が原因である と推察される. 